Netice Duman

Ertan Buyruk

Halil İbrahim Acar

Mustafa Caner $\bowtie$

Ferhat Kilinç

Ahmet Can

https://doi.org/10.21278/TOF.45Si1006321

ISSN 1333-1124

eISSN 1849-1391

\title{
EXERGY ANALYSIS OF A GROUND SOURCE HEAT PUMP SYSTEM FOR COLD CLIMATIC CONDITION OF SIVAS, TURKEY
}

\begin{abstract}
Summary
In the present study, exergy analysis of a ground source heat pump (GSHP) is performed. For this purpose, a horizontal type GSHP test system is installed at Sivas Cumhuriyet University in Sivas Province. GSHP system consists of three main circuits. These are the ground heat exchanger (GHE), the heat pump (HP) and the heating circuit. The temperatures and pressures are measured at the various points of the system. Besides, the mass flow rate of the working fluid circulating in the GHE, heat pump and heat circuit are measured. In addition, power consumption of the compressor and the pumps are measured. Measured data were recorded every minute. The test data used in the calculations are related to the coldest day, December 18, 2016. Exergy loss, exergy efficiency, exergy loss ratio and thermodynamic perfect degree for each element of the system are computed. Exergy efficiency and thermodynamic perfect degree of the system are calculated as 0.27 and 0.86 respectively.
\end{abstract}

Key words: $\quad$ Ground source heat pump, exergy, exergy efficiency, exergy loss, exergy loss ratio, thermodynamic perfect degree

\section{Introduction}

In recent years, the reduction of fossil fuel reserves, environmental problems, energy policies and climate changes have led to alternative use of ground source heat pumps. Heat pumps are environmentally friendly because they do not have $\mathrm{CO}_{2}$ emissions. In this context, ground source heat pumps can be preferred in conventional air-conditioning applications against conventional devices.

Exergy analysis aims to more efficiently use energy by determining the location and actual size of exergy losses. By reducing inefficiencies of existing systems, it is possible to design more efficient energy systems. The exergy content of a system in thermodynamics is defined as the maximum amount of theoretical work extracted from the system as a result of the system coming into the dead state $\left(P_{0}\right.$ and $\left.T_{0}\right)$. 
In the past years, many researchers have conducted studies on the exergy analysis of ground source heat pump systems. Hepbaşl1 and Akdemir [1] established a vertical GSHP system at Ege University Solar Energy Institute. It is aimed to heat a $65 \mathrm{~m}^{2}$ room with $50 \mathrm{~m}$ vertical drilling application. Experiments were carried out to determine the performance of the experimental system using mass, energy and exergy relationships and to perform exergy analysis. Esen et al. [2] set up a horizontal soil-based heat pump system to determine the system performance and make economic analysis in a test room heated in Elazığ. The GSHP system was compared with conventional heating methods (electric resistance, fuel oil, liquid petroleum gas, coal, oil and natural gas), detailed cost analysis was presented, and repayment periods were determined. The GSHP system has shown economic advantages over the first 5 conventional heating methods mentioned. As a result of the experiments and analyses, it has been determined that the system is not an economical alternative to the use of natural gas. $\mathrm{Bi}$ et al. [3] conducted a comparative exergy analysis of a soil-based heat pump system for building heating and cooling systems. Exergy loss, exergy efficiency, exergy loss rate, exergy loss coefficient, and thermodynamic excellence degree relationships are derived. As a result of the study, they found that the loss of exergy in the heating mode was greater than the loss of exergy in the cooling mode and that the exergy efficiency of the entire system was lower than the exergy efficiency of the system elements. They reported that the highest exergy losses in their systems occurred in the heat exchanger and compressor. Bakırc1 et al. [4] studied the energy analysis of heating applications with a solar-powered vertical type closedloop ground source heat pump system in Erzurum. In this experimental study, they found the COP values of heat pump and system between 3.0-3.4 and 2.7-3.0, respectively. According to these results, they stated that the system could be used in Erzurum. Lia et al. [5] analysed exotherms of heating and cooling of ground and air source heat pump systems theoretically. In their work, they have introduced both ground source heat pump systems (GSHP) and air source heat pump systems (ASHP) exergetic properties based on the concepts of "cold exergy" and "hot exergy". It was stated that GSHP consumed less exergy than ASHP. Analyses show that the compressor requires the greatest number of exergy entries among the total exergy entries and that the exergy consumption is at the highest level. It has come to the conclusion that it is important to reduce electricity consumption, increase compressor efficiency, and minimize unnecessary exergy consumption.

Korkmaz [6] examined the work of the board GSHP systems in different regions of Turkey. It has been stated that energy, exergy and economic analyses are mostly used for different purposes. As a result of this analysis was the conclusion reached these systems can easily use in different regions of Turkey. Zhai et al. [7] set up a heat pump system designed for a meeting hall with a closed area of $180 \mathrm{~m}^{2}$ at Shanghai Jiao Tong University. The heat pump has a cooling capacity of $22.3 \mathrm{~kW}$ and an electricity consumption of $5.3 \mathrm{~kW}$. Accordingly, the heating capacity and the power consumption in the heating mode are 29.5 $\mathrm{kW}$ and $6.9 \mathrm{~kW}$ respectively. The ground heat exchanger consists of 9 vertical drilling wells. There is only one U-pipe with a diameter of $32 \mathrm{~m}$ in each borehole. The entire length of the U-tube is $580 \mathrm{~m}$. Experimental research has been done for both cooling and heating. After a year, the average temperature of the soil carried by the heat is about $18^{\circ} \mathrm{C}$. This temperature value is the same as the soil temperature in that region. As a result of the experiments made, GSHP systems can be applied in the buildings in Shanghai.

In this study, usability of horizontal ground source heat pump system in Sivas province was investigated. Sivas is one of the coldest cities in Turkey and this study is the first application in this city. Exergy loss, exergy efficiency, exergy loss rate and thermodynamic perfect degree of each system element were calculated by exergy analysis. Also exergy efficiency of heat pump and entire system were calculated. The results showed that the first priority was to improve the compressor. 


\section{Introducing the System}

The energy house built on the area of $30 \mathrm{~m}^{2}$ within the campus of Cumhuriyet University was established for the purpose of experimentally examining the effects of different insulation materials and insulation thicknesses on heat loss for Sivas province. In order to make the heat pump selection for the heating loads of the energy house must be known. The heating load values were taken from the previous study by Kilınç. He found the heating loads value changes between $4350 \mathrm{~W}$ and $4700 \mathrm{~W}$ [8]. Figure 1 shows a schematic representation of the system. The test system consists of three circuits, the soil heat exchanger circuit, the heat pump circuit and the heating circuit. The soil heat exchanger is made of PE100 (polyethylene) pipe with a working pressure of $2.5 \mathrm{~m}$ depth and 10 bar. Antifreeze water with $20 \%$ by mass of antifreeze in the soil heat exchanger is used as fluid. R410 A is used as the working fluid in the heat pump circuit. A radiator is used as a heater in the heating circuit.

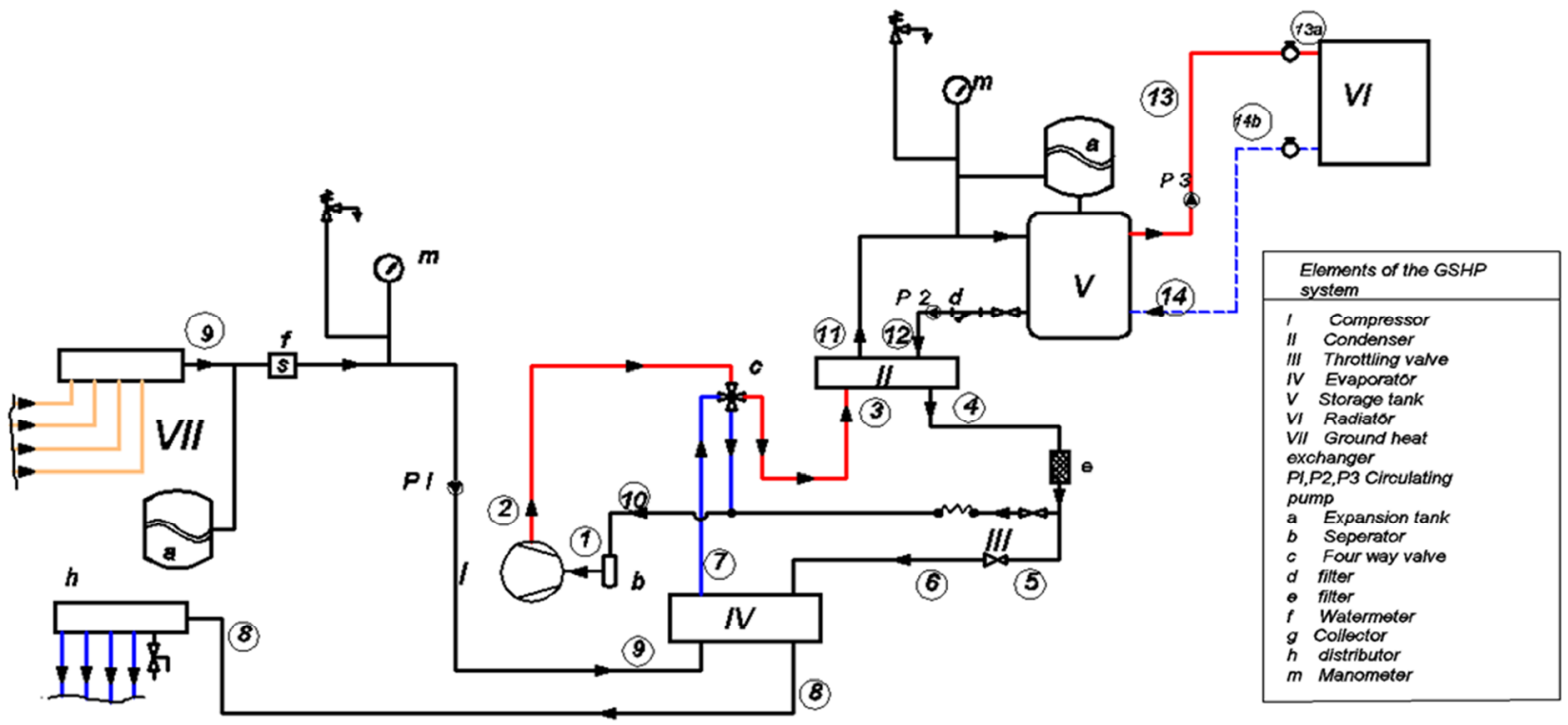

Fig. 1 The flowchart diagram of the GSHP system

The tests data used in the calculation are measured with a one-minute interval and recorded on the computer. The tests are carried out continuously throughout December 2016. These data are shown at measured value column in Table 1.

Table 1 System elements uncertainty values

\begin{tabular}{|c|c|c|}
\hline Measured values & unit & Total uncertainty (\%) \\
\hline Volumetric flow & $\mathrm{m}^{3} / \mathrm{h}$ & \pm 3.36 \\
\hline Temperature & ${ }^{\circ} \mathrm{C}$ & \pm 1.43 \\
\hline Power & $\mathrm{kW}$ & \pm 1.02 \\
\hline System Elements & & \\
\hline Compressor & $\mathrm{kW}$ & \pm 4.55 \\
\hline Condenser & $\mathrm{kW}$ & \pm 5.56 \\
\hline Evaporator & $\mathrm{kW}$ & \pm 5.56 \\
\hline Throttling valve & $\mathrm{kW}$ & \pm 2.04 \\
\hline Storage Tank & $\mathrm{kW}$ & \pm 2.04 \\
\hline Ground heat exchanger & $\mathrm{kW}$ & \pm 5.28 \\
\hline Radiator & $\mathrm{kW}$ & \pm 5.28 \\
\hline
\end{tabular}


N. Duman, E. Buyruk, H. İ. Acar, M. Caner, F. Kilinç, A. Can

Errors and uncertainties in experiments can be caused by device selection, device status, device calibration, environment, observation, and reading and test planning. An uncertainty analysis is required to demonstrate the correctness of the experimental work. Uncertainty analysis was performed using the method described by Holman [9], which is used in many studies.

\section{Exergy Analysis}

Energy analysis depends on the first law and concerns the conservation of energy. It does not give any knowledge about the change of the quality of energy in any unit. This information can only be determined by an exergy analysis based on the second law. Exergy analysis helps to make more efficient use of energy resources.

\subsection{General Analysis}

Conservation of mass, conservation of energy, and exergy balances equations are used in the analysis. A general conservation of mass balance can be expressed in rate form as follows:

$$
\sum \dot{m}_{\text {in }}=\sum \dot{m}_{\text {out }}
$$

where $\dot{m}$ is the mass flow rate, and the subscript in stands for inlet and out for outlet.

The principle of conservation of energy can be written for steady state flow system as follows:

$$
\dot{Q}-\dot{W}=\dot{m}_{\text {out }} h_{\text {out }}-\sum \dot{m}_{\text {in }} h_{\text {in }}
$$

Exergy balances can be written as follows:

$$
\dot{E} x_{\text {loss }}=\dot{E} x_{\mathrm{Q}}-\dot{E} x_{\mathrm{W}}+\sum \dot{E} x_{\text {mass,in }}-\sum \dot{E} x_{\text {mass,out }}
$$

The specific flow exergy of all streams has the next form:

$$
\psi=\left(h-h_{0}\right)-T_{0}\left(s-s_{0}\right)
$$

where $h$ is enthalpy, $\mathrm{s}$ is entropy, and the subscript zero indicates properties at the reference (dead) state (i.e., at $P_{0}$ and $T_{0}$ ).

The exergy losses per time, the exergy efficiencies, exergy loss rates and thermodynamic perfect degrees for specific elements of the system are given at Table 2 .

\section{System Exergy Analysis}

- Steady-state conditions exist.

- Heat transfer and refrigerant pressure drop in the pipeline connecting the components are negligible as their lengths are short.

- Potential and kinetic energies are neglected and there are no chemical reactions.

- The heat dissipation has been neglected in heat exchanger.

- Heat losses in the condenser and evaporator are neglected.

Schematic drawings and comprehensive exergy analysis for the components and the GSHP system are expressed in Table 2. 


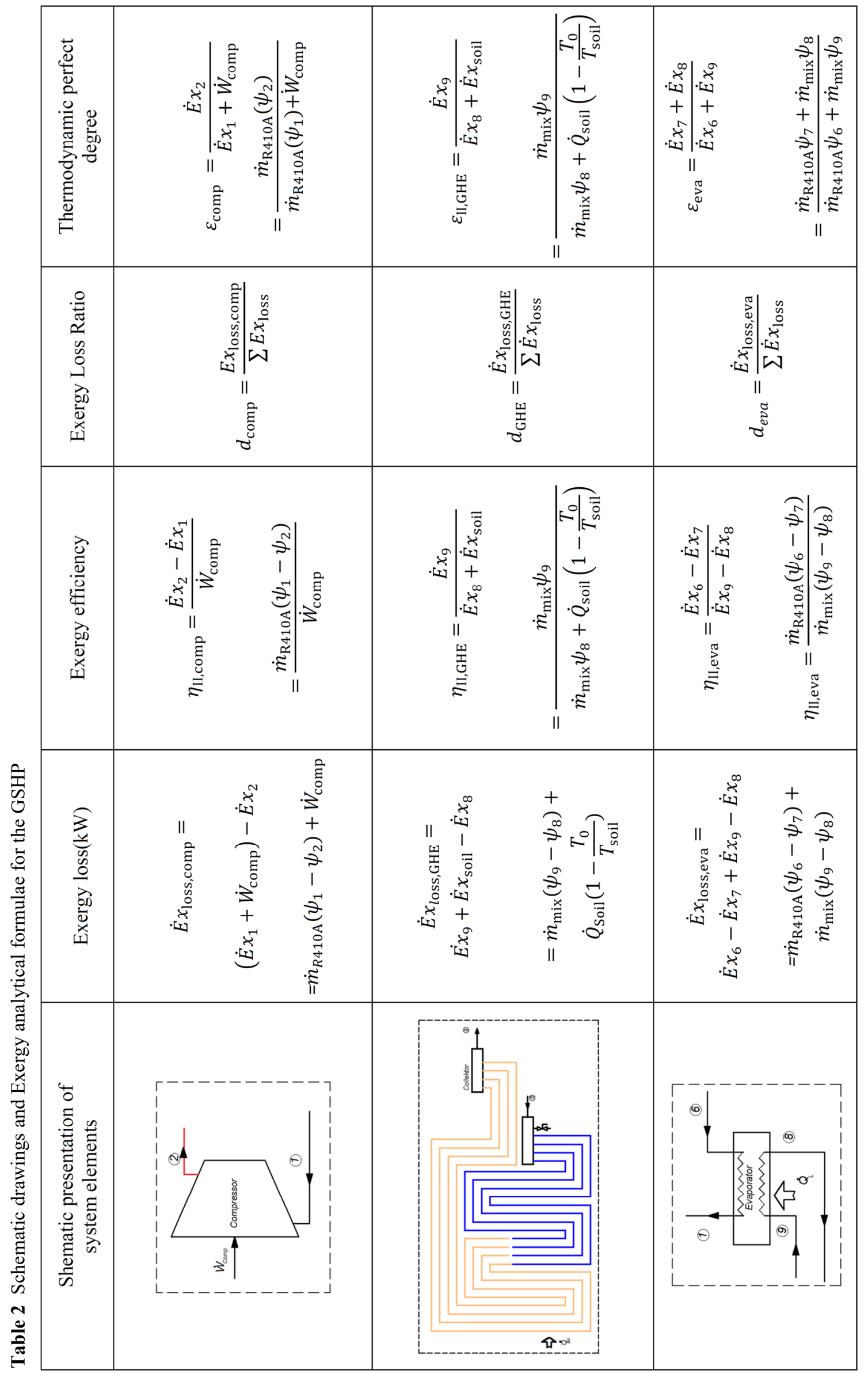


N. Duman, E. Buyruk, H. İ. Acar,

M. Caner, F. Kilinç, A. Can
Exergy Analysis of a Ground Source Heat Pump System for Cold Climatic Condition of Sivas, Turkey

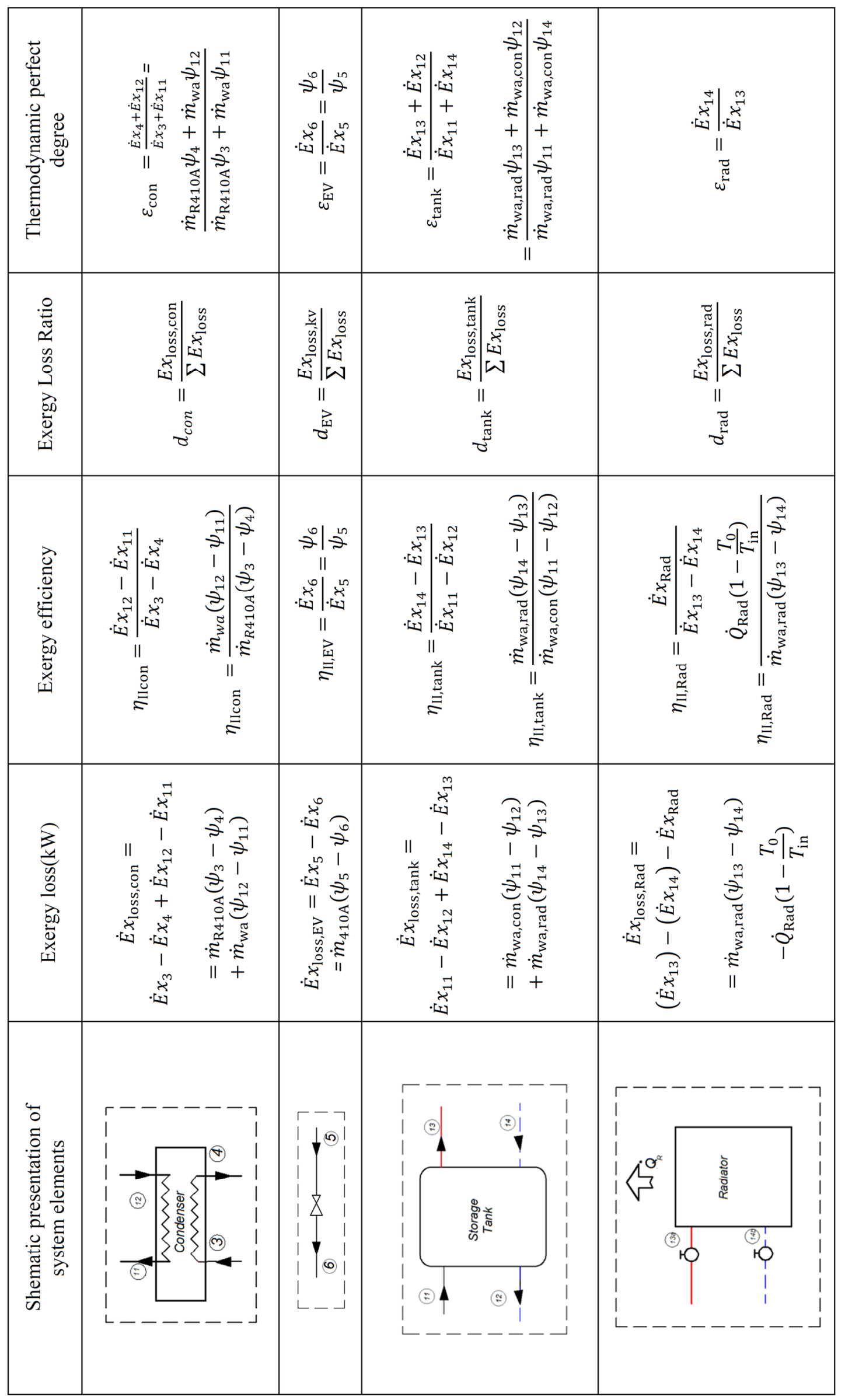




\section{Results and Discussion}

Exergy analysis aims to more efficient use energy by determining the location and actual size of exergy losses. By reducing inefficiencies of existing systems, it is possible to design more efficient energy systems. The exergy content of a system in thermodynamics is defined as the maximum amount of theoretical work extracted from the system as a result of the system coming into the dead state $\left(P_{0}\right.$ and $\left.T_{0}\right)$. In this study, the dead state temperature in accordance with the selections in the literature is taken as $1^{\circ} \mathrm{C}$ and the pressure is 1.013 bar.

For the date of December 18, 2016, which was the coldest day of December, exergy loss, exergy efficiency, exergy loss ratio and thermodynamic perfect degree are obtained for the system elements At this date, the outdoor temperature and the indoor temperature are measured as $-13.11^{\circ} \mathrm{C}, 23^{\circ} \mathrm{C}$ respectively. Figure 2 shows the exergy flow diagram. Exergy flow and exergy loss from each other using exergy flow and consumption values of each component of the system are shown in exergy flow diagrams [10]. These illustrations show the exergy flow to the external environment sequentially through the system components from each source marked in the $\mathrm{x}$ axis. The relative exergy content in the external environment is zero because the outdoor temperature is used as a reference condition for exergy analysis. The bar on the left side of each line shows the magnitude of the exergy input at the source and the contribution of the individual components. The slope of each line segment indicates the exergy consumption in the respective subsystem. The points between the individual components are marked according to the amount of exergy flow from one subsystem to another. In flow diagrams, the number in the orange box shows the exergy that is present in each element, the exergy given in green colours, and the exergy amounts transferred with the red arrows.

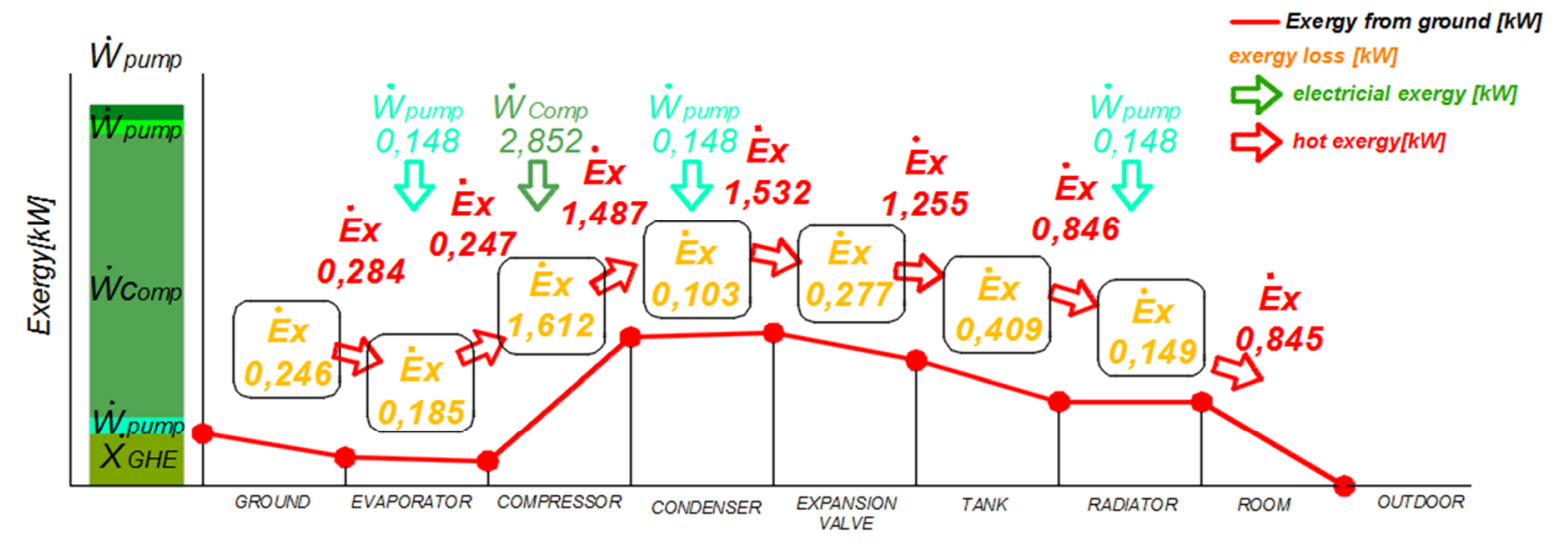

Fig. 2 Exergy flow diagram for GSHP

The comprehensive exergy analysis is performed for the components of the GSHP and results are listed in Table 3. The exergy loss of the circulation pumps is considered directly equal to their power consumption $(0.445 \mathrm{~kW})$. Exergy efficiency and thermodynamic perfect degree are the same for the throttling valve and GHE as shown in the Table 3. If these values are the same, the maximum exergy efficiency has been achieved. Other system components can be improved in terms of thermodynamics.

Figure 3 shows the change in exergy loss, exergy efficiency, exergy loss ratio and thermodynamics perfect degree values of GHE on 18 December 2016. As seen in the graphs, there is no change in these values during the day. 
N. Duman, E. Buyruk, H. İ. Acar, M. Caner, F. Kilinç, A. Can
Exergy Analysis of a Ground Source Heat Pump System for Cold Climatic Condition of Sivas, Turkey

Table 3 Exergy analysis results of the GSHP

\begin{tabular}{|c|c|c|c|c|}
\hline Component & $\begin{array}{c}\text { Exergy Loss } \\
\text { kW }\end{array}$ & $\begin{array}{c}\text { Exergy } \\
\text { Efficiency }\end{array}$ & $\begin{array}{c}\text { Exergy Loss } \\
\text { Ratio }\end{array}$ & $\begin{array}{c}\text { Thermodynamic } \\
\text { Perfect Degree }\end{array}$ \\
\hline Compressor & 1.610 & 0.436 & 0.470 & 0.67 \\
\hline Evaporator & 0.186 & 0.403 & 0.054 & 0.92 \\
\hline Condenser & 0.102 & 0.883 & 0.030 & 0.99 \\
\hline Expansion Valve & 0.278 & 0.880 & 0.080 & 0.88 \\
\hline GHE & 0.248 & 0.530 & 0.072 & 0.53 \\
\hline Tank & 0.409 & 0.472 & 0.119 & 0.96 \\
\hline Radiator & 0.151 & 0.587 & 0.044 & 0.96 \\
\hline
\end{tabular}
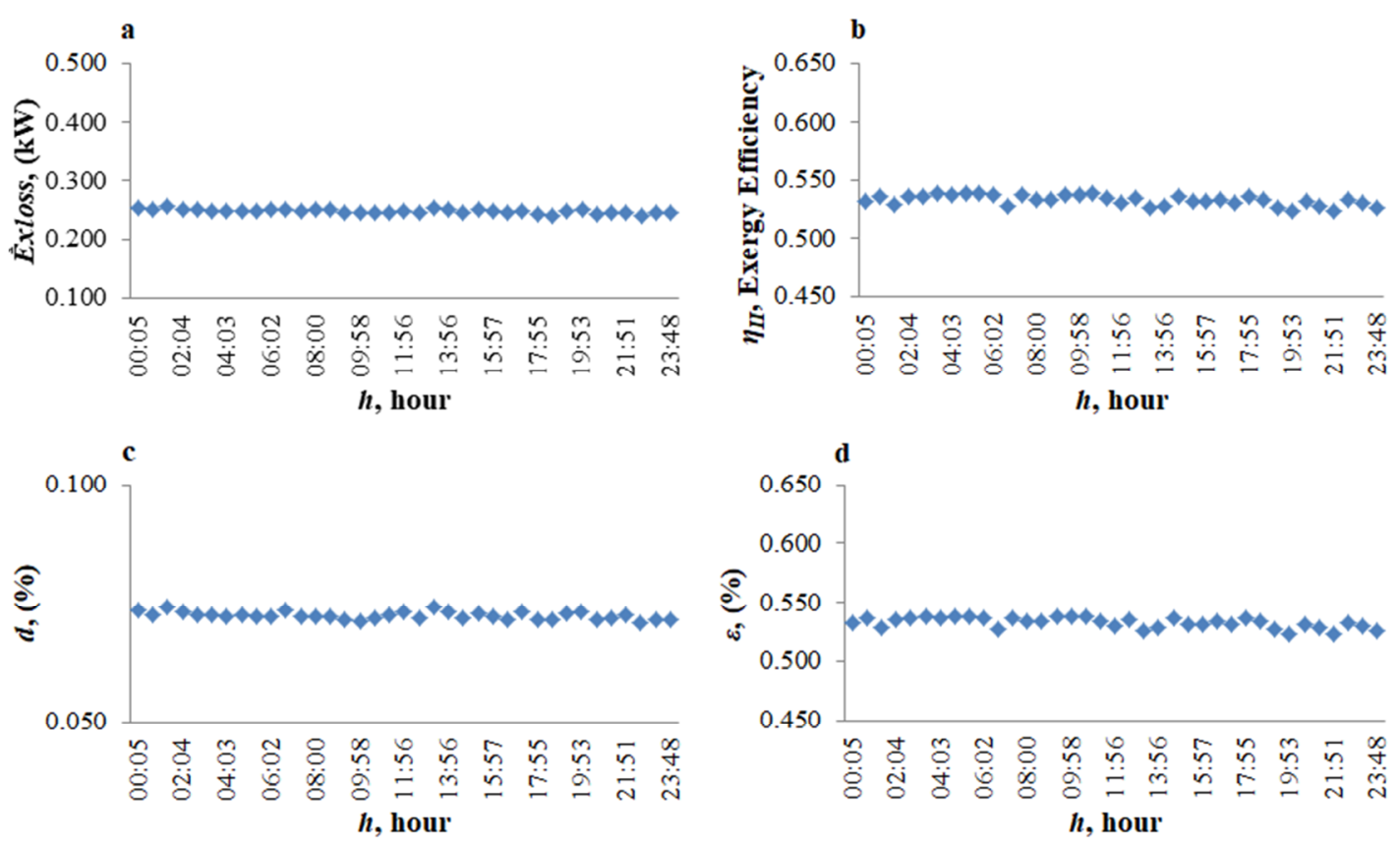

Fig. 3 Exergy loss (a), exergy efficiency (b), exergy loss ratio (c) and thermodynamic perfect degree (d) daily changes of GHE

The graphs of the other elements of the system are not drawn. Figure 4 shows the graph of exergy losses of the system elements.

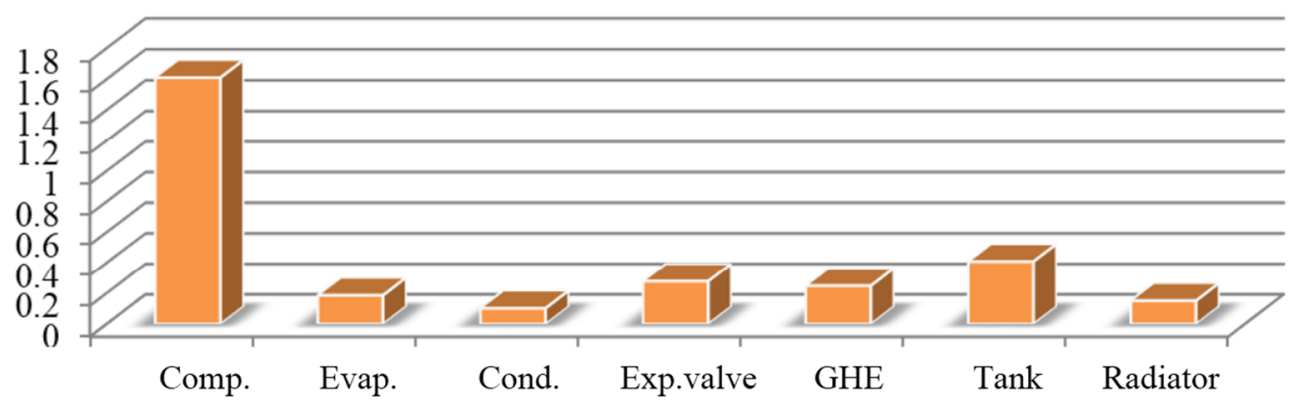

Fig. 4 Exergy loss of the GSHP system components on 18 December 2016

According to this graph, the maximum exergy loss is seen in the compressor. Losses in other elements are too small to be compared with the compressor. The values of exergy loss ratio exergy efficiency and thermodynamic perfect degree in December 18, 2016 are given in Figure 5. 


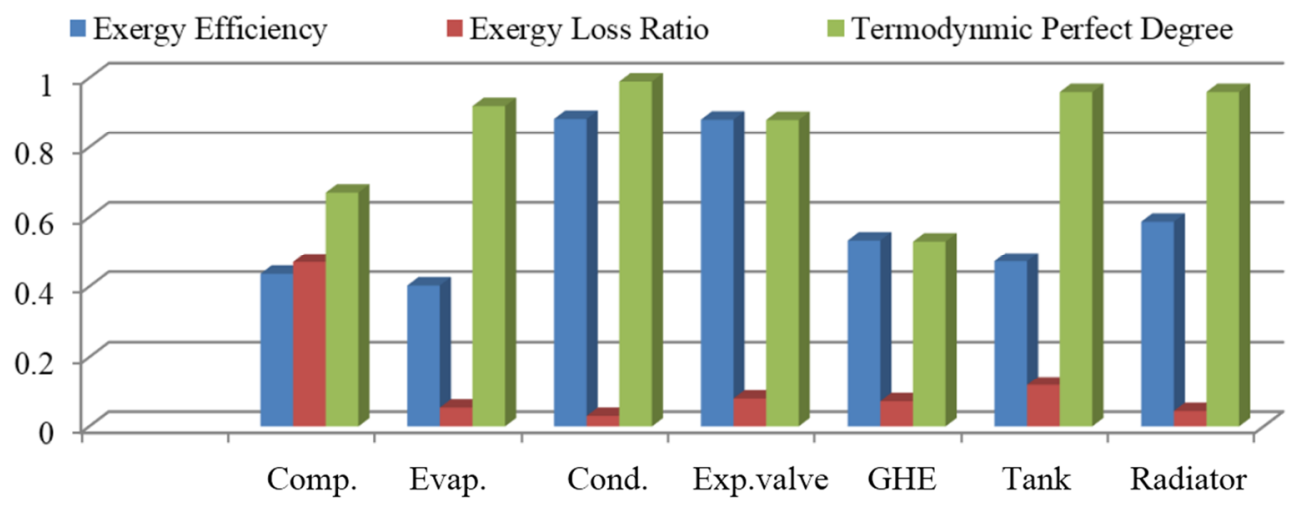

Fig. 5 Exergy loss ratio, exergy efficiency and thermodynamic perfect degree of the system components

Exergy efficiency is defined as the ratio of exergy output from the system or any system element to the exergy used in this system or element. The exergy loss ratio is the ratio of the exergy loss of each system element to the total exergy loss of the system. It contributes to identifying the improvements needed to reduce exergy losses in the system. The thermodynamic perfect degree is the ratio of exergy from the device or system to the exergy entering the device or system and shows the effect of irreversibility during the operation on the energy consuming device or system. As shown in figure 5, the highest exergy efficiency occurs in the condenser, the biggest exergy loss ratio occurs in the compressor. As the smallest thermodynamic perfect degree is in the compressor, it is necessary to focus on the compressors for improvements. The irreversibility of the compressor resulted in a 33\% reduction in the thermodynamic perfect degree. Similar results are obtained in the other studies. Bi et al. [3] reported the thermodynamic perfection degree as $97 \%$. In the present study, this value was determined as $98.9 \%$ in accordance with the literature. The thermodynamic perfect degree in the accumulation tank is calculated $96 \%$. The thermodynamic perfect degree of radiator is calculated 96\%. Badescu [11], Akpinar et al. [12], Ozgener et al. [13] and $\mathrm{Bi}$ et al. [3] reported that the biggest exergy loss occurred in the compressor. In the present study, the biggest loss of exergy is realized in the compressor.

\section{Conclusions}

According to these results, it is observed that the horizontal GSHP system, which is built first in Sivas province, is not sufficient for long term heating purposes for Sivas province. In order to make the GSHP system more attractive, measurements can be taken such as supporting the system with solar energy, heating the water from the underground circuit and integrating with the photovoltaic panels on the basis of the building. Also, in the design of ground source heat pumps, winter and summer heating and cooling loads should be kept as close to each other as possible, seasonal thermal equilibrium should be ensured and necessary precautions should be taken in order to prevent the soil from reaching a certain saturation limit in heating or cooling mode. Lowering the outlet temperature of the refrigerant from the compressor (for example at $50{ }^{\circ} \mathrm{C}$ ), reducing the condenser inlet and outlet temperatures and increasing the inlet and outlet temperatures of the evaporator will reduce the exergy losses in the compressor and increase the efficiency.

\section{NOMENCLATURE}

\begin{tabular}{|c|c|c|c|c|c|}
\hline$\dot{\boldsymbol{E}}$ & Exergy $[\mathrm{kJ}, \mathrm{kW}]$ & $\boldsymbol{\eta}$ & Efficiency [\%] & eva & Evaporator \\
\hline$\dot{\boldsymbol{E}} \boldsymbol{x}_{\text {loss }}$ & Exergy loss $[\mathrm{kW}]$ & $\boldsymbol{d}$ & Exergy loss ratio & mix & Antifreeze and water mixture \\
\hline$\dot{\boldsymbol{m}}$ & Mass flow rate $[\mathrm{kg} / \mathrm{s}]$ & $\boldsymbol{\varepsilon}$ & Thermodynamic perfect degree & con & Condenser \\
\hline$\dot{\boldsymbol{Q}}$ & Heat transfer rate $[\mathrm{kW}]$ & $\boldsymbol{G S H P}$ & Ground source heat pump & tank & Storage tank \\
\hline$\dot{\boldsymbol{W}}$ & Power $[\mathrm{kW}]$ & $\boldsymbol{G H} \boldsymbol{E}$ & Ground heat exchanger & rad & Radiator \\
\hline $\boldsymbol{h}$ & Specific enthalpy $[\mathrm{kJ} / \mathrm{kg}]$ & $\mathbf{0}$ & Reference (outdoor) condition & pump & Circulation pump \\
\hline $\boldsymbol{\psi}$ & Specific flow exergy & $\mathbf{c o m p}$ & Compressor & & \\
\hline
\end{tabular}


N. Duman, E. Buyruk, H. İ. Acar,

M. Caner, F. Kilinç, A. Can
Exergy Analysis of a Ground Source Heat Pump System for Cold Climatic Condition of Sivas, Turkey

\section{Acknowledgements}

This study is supported by Sivas Cumhuriyet University Scientific Research Projects (CUBAP) commission within the scope of M-617 project.

\section{REFERENCES}

[1] Hepbasli, A., Akdemir, O., Energy and exergy analysis of a ground source (geothermal) heat pump system. Energy Conversion and Management, 45(5), 737-753, 2004. https://doi.org/10.1016/s0196-8904(03)00185-7

[2] Esen, H., Inalli, M., Esen, M., Technoeconomic appraisal of a ground source heat pump system for a heating season in eastern Turkey. Energy Conversion and Management, 47(9-10), 1281-1297, 2006. https://doi.org/10.1016/j.enconman.2005.06.024

[3] Bi., Y., Wang, X., Liu, Y., Zhang, H., Chen, L., Comprehensive exergy analysis of a ground-source heat pump system for both building heating and cooling modes. Applied Energy, 86(12), 2560-2565, 2009. https://doi.org/10.1016/j.apenergy.2009.04.005

[4] Bakirci, K., Ozyurt, O., Comakli, K., Comakli, O., Energy analysis of a solar-ground source heat pump system with vertical closed-loop for heating applications. Energy, 36: 3224-3232, 2011. https://doi.org/10.1016/j.energy.2011.03.011

[5] Lia, R, Ookab, R. Shukuyaca, M., Theoretical analysis on ground source heat pump Rand air source heatpump systems by the concepts of cool and warm exergy Graduate Energy and Buildings 75 447-455, 2014. https://doi.org/10.1016/j.enbuild.2014.02.019

[6] Korkmaz, M., Ground Source Heat Pump Systems with dwellings heated by the Scientific Evaluation of Relevant Made in Turkey. ISITES2015 Valencia-Spain, 2015.

[7] Zhai, X. Q., Cheng, X. W., Wang, R. Z., Heating and cooling performance of a minitype ground source heat pump system. Applied Thermal Engineering, 111, 1366-1370, 2017. https://doi.org/10.1016/j.applthermaleng.2016.03.117

[8] Kılınç, F., Experimental and numerical analysis of the effects of different insulation materials on heat loss for Sivas. M.Sc. Thesis, Cumhuriyet University, Institute of Science and Technology, Sivas, 2011.

[9] Holman, J.P., Experimental methods for Engineers, McGraw-Hill Education, 739s, 1994.

[10] Menberg, K., Heo, Y., Choi, W., Ooka, R., Choudhary, R., Shukuya, M., Exergy analysis of a hybrid ground-source heat pump system. Applied Energy, 204, 31-46, 2017. https://doi.org/10.1016/j.apenergy.2017.06.076

[11] Badescu, V., First and second law analysis of a solar assisted heat pump based heating system. Energy Conversion and Management, 43(18), 2539-2552, 2002. https://doi.org/10.1016/s0196-8904(01)00192-3

[12] Akpınar, E. K. and Hepbaşl1, A., A Comperative Study on Exergetic Assessment of Two GroundSource(Geothermal) Heat Pump Systems for Residential Application, Building and Environment, 42: 2004-2013, 2007. https://doi.org/10.1016/j.buildenv.2006.04.001

[13] Ozgener, O. and Hepbasli, A., A review on the energy and exergy analysis of solar assisted heat pump systems. Renewable and Sustainable Energy Reviews, 11(3), 482-496, 2007. https://doi.org/10.1016/j.rser.2004.12.010

Submitted:

19.6.2019

Accepted:
28.8.2020
Assist. Prof. Netice Duman

Sivas Cumhuriyet University, Vocational

High School, Sivas, Turkey

Prof. Dr. Ertan Buyruk

Prof. Dr. H. İbrahim Acar

Res. Asst. Mustafa Caner

Assist. Prof. Ferhat Kilinç

Sivas Cumhuriyet University, Mechanical

Eng. Dept., Sivas, Turkey

Prof. Dr.-Ing Ahmet Can

Istanbul Rumeli University Institute of

Science Faculty of Eng. and Arc.

Istanbul, Turkey 